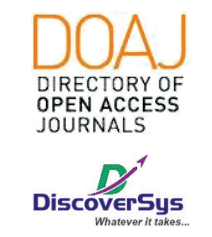

Published by DiscoverSys

\section{Profil anak dengan ketergantungan internet di SMPN 2 Denpasar}

\author{
I Gusti Ngurah Agung Jayadhi Widyakusuma, ${ }^{1 *}$ I Made Darma Yuda, ${ }^{2}$ \\ I Gusti Ngurah Made Suwarba ${ }^{3}$
}

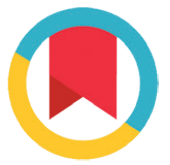

CrossMark

\title{
ABSTRACT
}

Background: The internet is technology that developed is very fast in recent years. Development of internet may occur positive and negative effect. Survey that conducted in 2017 in Indonesia, according to gender showed that males $(51,43 \%)$ are more than females in using the internet. The purpose of this research was to know internet addiction profiles and relationship between internet addiction and gender in SMPN 2 Denpasar students.

Methods: The study design was a cross sectional study with total sampling. The data were taken from students by using questionnaire at SMPN 2 Denpasar. The result was analyzed by univariate and bivariate method using chi-square test.

Results: There are 366 subjects included in this study. 198 samples were males, and 168 samples were females. Based on the analyzed result, it confirmed that the internet addiction relates significantly with gender ( $p$-value $=0.048)(p<0.05)$. Univariate analysis showed that $21,8 \%$ were suffer mild internet addiction and 4,3\% were suffer moderate internet addiction. Males were suffering internet addiction more than females. Internet was mainly used to play game online and chatting were smartphone are the most device-used to access the internet. Basic needs were the most activities that can stop internet access. The most duration of internet usage are 2-4 hours/day and $<40$ hours/week.

Conclusions: From the result of this study, can be concluded that there is a significant relationship between internet addiction and gender in SMPN 2 Denpasar students.

Keywords: Internet addiction, Gender

Cite This Article: Widyakusuma, I.G.N.A.J., Yuda, I.M.D., Suwarba, I.G.N.M. 2019. Profil anak dengan ketergantungan internet di SMPN 2 Denpasar. Intisari Sains Medis 10(3): 791-796. D0I: 10.15562/ism.v10i3.472

\section{ABSTRAK}

Latar Belakang: Internet merupakan teknologi yang berkembang pesat dalam beberapa tahun terakhir. Perkembangan internet dapat menimbulkan berbagai dampak positif dan negatif. Survei tahun 2017 di Indonesia, komposisi pengguna internet di Indonesia berdasarkan jenis kelaminmenunjukkan bahwalaki-laki (51,43\%) lebih banyak dibandingkan perempuan (48,57\%). Tujuan penelitian ini adalah mengetahui profil kejadian ketergantungan internet dan hubungan ketergantungan internet terhadap jenis kelamin pada siswa SMPN 2 Denpasar.

Metode: Desain penelitian adalah cross-sectional study dengan total sampling. Data bersumber dari kuisoner yang diisi oleh siswa SMPN

${ }^{1}$ Dokter umum RSIA Puri Bunda, Denpasar, Bali

${ }^{2}$ Dokter Spesialis Anak RSIA Puri Bunda, Denpasar, Bali

${ }^{3}$ Departemen/SMF Ilmu Kesehatan Anak RSUP Sanglah, Fakultas Kedokteran Universitas Udayana

*Korespondensi: I G N Agung Jayadhi Widyakusuma, Dokter umum RSIA Puri Bunda,

Denpasar, Bali

jayadhi_widyakusuma@yahoo.com

Diterima: 02-04-2019

Disetujui: 21-11-2019

Diterbitkan: 01-12-2019

Kata kunci: Ketergantungan internet, Jenis kelamin Intisari Sains Medis 10(3): 791-796. D0I: 10.15562/ism.v10i3.472

Internet merupakan teknologi yang berkembang pesat dalam beberapa tahun terakhir. Perkembangan ketergantungan internet berhubungan secara bermakna dengan jenis kelamin $p=0.048 \quad(p<0.05)$. Sebanyak $21,8 \%$ responden mengalami ketergantungan internet ringan dan 4,3\% mengalami ketergantungan internet sedang. Berdasarkan jenis kelamin, lakilaki lebih banyak mengalami ketergantungan internet. Penggunaan internet terbanyak adalah untuk bermain game online dan chatting. Smartphone merupakan gawai terbanyak yang digunakan untuk mengakses internet. Kebutuhan dasar merupakan kegiatan yang paling dominan menghentikan kegiatan berinternet. Durasi menggunakan internet terbanyak adalah 2-4 jam dalam sehari dan $<40$ jam dalam seminggu.

Simpulan: Berdasarkan hasil penelitian ini dapat disimpulkan bahwa terdapat hubungan yang bermakna antara kecanduan internet dengan jenis kelamin pada siswa SMPN 2 Denpasar.

Cite Pasal Ini: Widyakusuma, I.G.N.A.J., Yuda, I.M.D., Suwarba, I.G.N.M. 2019. Profil anak dengan ketergantungan internet di SMPN 2 Denpasar.

\section{PENDAHULUAN} internet dapat menimbulkan berbagai dampak positif dan negatif. ${ }^{1}$ Ketergantungan internet dapat menjadi gangguan yang serius dalam perkembangan anak termasuk dalam bagaimana 
memanajemen waktu hingga bersosialisasi di kehidupan sehari-hari. Hasil survei tahun 2017 di Indonesia menunjukkan jumlah pengguna internet di Indonesia mencapai 143,26 juta jiwa $(54,68 \%)$ dari total penduduk Indonesia yaitu sebanyak 262 juta orang. Secara demografi, Jawa $(58,08 \%)$ menduduki peringkat pertama dalam jumlah pengguna internet, sedangkan Bali-Nusa $(5,63 \%)$ menduduki peringkat 5 di Indonesia. Jika dilihat berdasarkan penetrasi pengguna internet di Indonesia, Bali-Nusa (54,23\%) menduduki peringkat ketiga dibawah Kalimantan (72,19\%) dan Jawa (57,70\%). Komposisi pengguna internet di Indonesia berdasarkan jenis kelamin menunjukkan bahwa laki-laki $(51,43 \%)$ lebih banyak dibandingkan perempuan $(48,57 \%)$. Komposisi pengguna internet di Indonesia menurut umur menunjukkan jumlah terbanyak pada usia produktif yaitu umur 19-24 tahun (49,52\%). Usia remaja yaitu berumur 13-18 tahun sebesar $16,68 \%$ merupakan penetrasi pengguna internet terbesar di Indonesia $(75,50 \%){ }^{2}$

Remaja berumur 14-19 tahun yang pada umumnya sekolah pada Sekolah Menengah Pertama atau Sekolah Menengah Atas sudah dibekali dengan gawai sedari kecil oleh orang tua mereka. Penggunaan gawai tanpa pengawasan ataupun edukasi yang cukup mengenai dampak buruk yang mungkin akan terjadi menyebabkan tidak terkontrolnya waktu yang digunakan para remaja yang dihabiskan untuk berinternet. Penggunaan internet pada remaja dapat meningkatkan kejadian ketergantungan internet. ${ }^{3}$ Jenis kelamin ikut berperan dalam ketergantungan internet. Pada perempuan, internet digunakan untuk media sosial, belanja online, dan berkomunikasi dengan teman sebaya. Pada laki-laki, internet digunakan untuk online gaming dan komunikasi dengan teman sebaya. Berdasarkan hal tersebut, dapat diketahui jenis ketergantungan internet pada lakilaki maupun perempuan. ${ }^{4}$ Durasi penggunaan internet sangat berpengaruh pada kecenderungan individu untuk jatuh ke dalam ketergantungan internet. Penggunaan internet secara terus-menerus lebih dari 4 jam dalam sehari dapat meningkatkan kecenderungan mengalami ketergantungan internet. ${ }^{5}$ Ketergantungan internet tampaknya menjadi gangguan yang umum terjadi yang sesuai dengan kriteria DSM-V. ${ }^{6}$ Ketergantungan internet dapat dianggap sebagai gangguan kontrol dorongan keinginan. ${ }^{78}$ Ketergantungan internet akan berdampak tidak baik bagi perkembangan otak, psikologis hingga akhirnya mempengaruhi prestasi sekolah maupun komunikasi antar sesama. Berdasarkan latar belakang tersebut, peneliti ingin mengetahui profil anak dengan ketergantungan internet dan hubungan ketergantungan internet dengan jenis kelamin pada siswa SMPN 2 Denpasar.

\section{METODE}

Penelitian ini adalah studi observasional dengan desain cross sectional terhadap populasi siswa SMPN 2 Denpasar. Pengambilan data dilakukan pada Februari 2019 dalam satu hari mengambilan dengan metode pengambilan sampel menggunakan total sampling yaitu mengambil seluruh siswa SMPN 2 Denpasar yang hadir di kelas dan bersedia mengisi kuisioner pada hari itu.

Data penelitian didapatkan melalui kuisioner yang terdiri dari 2 bagian. Bagian pertama mengunakan kuesioner Internet Addiction Test (IAT) versi Bahasa Indonesia yang telah disesuaikan berisi 17 pertanyaan dan bagian kedua berisi data umum yang berkaitan dengan aktivitas di internet, gawai yang digunakan, aktivitas yang menghentikan kegiatan berinternet, dan waktu yang digunakan untuk berinternet. Analisa data dilakukan secara bertahap yaitu analisa univariat dan analisa bivariat menggunakan chi-square test.

\section{HASIL}

Setelah dilakukan proses pengambilan data, didapatkan 369 siswa SMPN 2 Denpasar yang mengisi dan mengembalikan kuesioner. Sebanyak 366 diantaranya memenuhi kriteria untuk dilakukan pengolahan data. Didapatkan 198 orang responden laki-laki dan 168 orang responden perempuan.

Berdasarkan Tabel 2, didapatkan bahwa game online merupakan aktivitas tersering yang dilakukan oleh responden laki-laki sedangkan chatting atau berbalas pesan online merupakan aktivitas yang paling sering dilakukan oleh responden perempuan.

Smartphone merupakan gawai yang paling sering digunakan. Sebanyak 182 laki-laki dan 159 perempuan menggunakan smartphone sebagai gawai yang paling sering digunakan untuk berinternet (Tabel 3). Kebutuhan dasar merupakan aktivitas yang paling dominan yang dapat menghentikan kegiatan online (Tabel 4).

Berdasarkan Tabel 5, Ketergantungan internet ringan menghabiskan waktu berinternet dalam sehari dominan antara 2-4 jam hingga 5-8 jam yaitu masing-masing sebanyak 30 orang, sedangkan pada ketergantungan internet sedang paling banyak menghabiskan waktu $>8$ jam sehari yaitu sebanyak 10 orang.

Ketergantungan internet ringan dominan menghabiskan waktu $<40$ jam dalam seminggu yaitu sebanyak 42 orang. Sedangkan pada ketergantungan internet sedang dominan menghabiskan waktu 40 jam dalam seminggu yaitu sebanyak 11 orang (Tabel 6). Berdasarkan uji chi-square didapatkan bahwa nilai p sebesar $0.048(\mathrm{p}<0.05)$ (Tabel 7). Hal 
Tabel 1 Karakteristik Sampel

\begin{tabular}{|c|c|c|c|}
\hline \multirow[b]{2}{*}{ Karakteristik Subjek Penelitian } & \multicolumn{2}{|c|}{ Jenis Kelamin } & \multirow[b]{2}{*}{ Total } \\
\hline & Laki-Laki & Perempuan & \\
\hline \multicolumn{4}{|l|}{ Umur } \\
\hline 12 tahun & 18 & 12 & 30 \\
\hline 13 tahun & 26 & 31 & 57 \\
\hline 14 tahun & 72 & 64 & 136 \\
\hline 15 tahun & 74 & 56 & 130 \\
\hline 16 tahun & 7 & 3 & 10 \\
\hline 17 tahun & 0 & 2 & 2 \\
\hline 19 tahun & 1 & 0 & 1 \\
\hline \multicolumn{4}{|l|}{ Tingkat Ketergantungan Internet } \\
\hline Normal & 137 & 133 & 270 \\
\hline Ringan & 53 & 27 & 80 \\
\hline Sedang & 8 & 8 & 16 \\
\hline Berat & 0 & 0 & 0 \\
\hline \multicolumn{4}{|l|}{ Gawai yang paling sering digunakan } \\
\hline Laptop/PC & 9 & 7 & 16 \\
\hline$P C$ public/Warnet & 5 & 1 & 6 \\
\hline Smartphone & 182 & 159 & 341 \\
\hline Tablet & 2 & 1 & 3 \\
\hline \multicolumn{4}{|c|}{ Aktivitas yang menghentikan kegiatan online } \\
\hline Aktivitas sosial & 49 & 35 & 84 \\
\hline Belajar & 33 & 37 & 70 \\
\hline Ibadah & 38 & 29 & 67 \\
\hline Kebutuhan dasar & 66 & 59 & 125 \\
\hline Sekolah & 12 & 8 & 20 \\
\hline \multicolumn{4}{|l|}{ Aktivitas tersering di internet } \\
\hline Web surfing & 16 & 22 & 38 \\
\hline Game online & 114 & 24 & 138 \\
\hline Belanja online & 2 & 2 & 4 \\
\hline Chatting & 62 & 117 & 179 \\
\hline Konten dewasa & 4 & 3 & 7 \\
\hline \multicolumn{4}{|c|}{ Waktu menggunakan internet dalam sehari } \\
\hline $2-4$ jam & 126 & 88 & 214 \\
\hline 5-8 jam & 49 & 53 & 102 \\
\hline$>8$ jam & 23 & 27 & 50 \\
\hline \multicolumn{4}{|c|}{ Waktu menggunakan internet dalam seminggu } \\
\hline$<40$ jam & 116 & 84 & 200 \\
\hline$>40$ jam & 82 & 84 & 166 \\
\hline
\end{tabular}

Tabel 2 Gambaran jenis kelamin berdasarkan aktivitas yang paling sering dilakukan saat berinternet

\begin{tabular}{lccccc}
\hline \multirow{2}{*}{$\begin{array}{l}\text { Jenis } \\
\text { kelamin }\end{array}$} & $\begin{array}{c}\text { Web } \\
\text { Surfing }\end{array}$ & $\begin{array}{c}\text { Game } \\
\text { Online }\end{array}$ & $\begin{array}{c}\text { Belanja } \\
\text { online }\end{array}$ & Chatting & $\begin{array}{c}\text { Konten } \\
\text { Dewasa }\end{array}$ \\
\hline Laki-laki & 16 & 114 & 2 & 62 & 4 \\
Perempuan & 22 & 24 & 2 & 117 & 3 \\
Total & 38 & 138 & 4 & 179 & 7 \\
\hline
\end{tabular}

ini menunjukkan bahwa terdapat hubungan antara ketergantungan internet dengan jenis kelamin pada siswa SMPN 2 Denpasar.

\section{DISKUSI}

Aktivitas yang dominan dilakukan dalam menggunakan internet berbeda antara laki-laki dan perempuan. Aktivitas yang dilakukan dalam menggunakan internet pada laki-laki cenderung menggunakan internet untuk game online. Pada perempuan, aktivitas yang dilakukan saat menggunakan internet lebih pada chatting/ pesan online. Hal ini sesuai dengan penelitian yang dilakukan oleh Joseph C, dkk (2015) dalam sebuah studi mengenai perilaku dalam menggunakan internet berdasarkan jenis kelamin. Penelitian tersebut menunjukkan bahwa laki-laki lebih cenderung melakukan aktivitas game saat berinternet dibandingkan dengan perempuan. Perempuan umumnya lebih sering melakukan aktivitas chatting/pesan online jika menggunakan internet. ${ }^{9}$

Gawai berperan penting dalam akses internet karena gawai merupakan media untuk dapat menggunakan internet. Penelitian ini mendapatkan gawai yang paling sering digunakan untuk mengakses internet adalah Smartphone. Smartphone digunakan oleh sebagian besar responden baik pada laki-laki ataupun perempuan. Smartphone juga sebagai gawai yang paling sering digunakan pada sampel yang mengalami ketergantungan internet ringan hingga sedang. Smartphone sangat dominan digunakan sebagai alat untuk mengakses internet karena kemudahan yang diberikan yaitu praktis untuk dibawa dan digunakan. Hasil tersebut juga menjelaskan laki-laki dan perempuan pada umur tersebut masuk dalam kelompok remaja yang menggunakan smartphone untuk keperluan media sosial, berlajar ataupun untuk menjalin hubungan dengan lawan jenis dan aktivitas tersebut revelan pada kedua jenis kelamin tersebut. ${ }^{10}$ Temuan pada penelitian ini sesuai dengan penelitian yang dilakukan oleh Miftahul J (2017) dalam penelitiannya mendapatkan smartphone merupakan gawai yang paling banyak digunakan untuk mengakses internet. ${ }^{11}$

Penggunaan internet merupakan salah satu aktivitas dalam kegiatan sehari-hari. Terdapat kegiatan atau kebutuhan lain yang perlu dilakukan agar dapat menjalani kehidupan dengan baik seperti makan, mandi, tidur, bersekolah, ibadah, belajar, dan kegiatan sosial dengan sesama. Pada penelitian ini mendapatkan bahwa kebutuhan dasar seperti makan, mandi, dan tidur merupakan aktivitas yang paling dominan sebagai penghenti kegiatan online. Sekolah merupakan aktivitas terendah sebagai penghenti kegiatan online. Peneliti berpendapat 
Tabel 3 Gambaran kejadian ketergantungan internet berdasarkan gawai yang paling sering digunakan

\begin{tabular}{lcccc}
\hline & \multicolumn{4}{c}{ Jenis Gawai } \\
\cline { 2 - 5 } Jenis kelamin & Laptop/PC & PC public/warnet & Smartphone & Tablet \\
\hline Laki-laki & 9 & 5 & 182 & 2 \\
Perempuan & 7 & 1 & 159 & 1 \\
Total & 16 & 6 & 341 & 3 \\
\hline
\end{tabular}

Tabel 4 Gambaran kegiatan yang dapat menghentikan kegiatan online

\begin{tabular}{lc}
\hline Aktivitas & Frekuensi \\
\hline Aktivitas sosial & 84 \\
Belajar & 70 \\
Ibadah & 67 \\
Kebutuhan Dasar & 125 \\
Sekolah & 20 \\
Total & 366 \\
\hline
\end{tabular}

Tabel 5 Gambaran ketergantungan internet berdasarkan waktu berinternet dalam sehari

\begin{tabular}{lccc}
\hline \multirow{2}{*}{$\begin{array}{l}\text { Tingkat Kecanduan } \\
\text { Internet }\end{array}$} & \multicolumn{3}{c}{ Waktu Menggunakan Internet dalam Sehari } \\
\cline { 2 - 4 } & $\mathbf{2 - 4}$ jam & $\mathbf{5 - 8}$ jam & $\mathbf{> 8 ~ j a m ~}$ \\
\hline Normal & 183 & 67 & 20 \\
Ringan & 30 & 30 & 20 \\
Sedang & 1 & 5 & 10 \\
Total & 214 & 102 & 50 \\
\hline
\end{tabular}

Tabel 6 Gambaran ketergantungan internet berdasarkan waktu berinternet dalam seminggu

\begin{tabular}{llll}
\hline \multirow{2}{*}{$\begin{array}{l}\text { Tingkat Kecanduan } \\
\text { Internet }\end{array}$} & \multicolumn{2}{c}{ Waktu Menggunakan Internet dalam Seminggu } \\
\cline { 2 - 3 } & \multicolumn{2}{c}{$<\mathbf{4 0}$ jam } & >40 jam \\
\hline Normal & 153 & 117 \\
Ringan & 42 & 38 \\
Sedang & 5 & 11 \\
Total & 200 & 166 \\
\hline
\end{tabular}

Tabel 7 Gambaran kejadian ketergantungan internet berdasarkan jenis kelamin

\begin{tabular}{|c|c|c|c|c|}
\hline \multirow[b]{2}{*}{ Jenis Kelamin } & \multicolumn{3}{|c|}{ Waktu Menggunakan Internet dalam Sehari } & \multirow[b]{2}{*}{$\mathbf{P}$} \\
\hline & 2-4 jam & 5-8 jam & $>8$ jam & \\
\hline Laki - laki & 137 & 53 & 8 & \multirow{3}{*}{0.048} \\
\hline Perempuan & 133 & 27 & 8 & \\
\hline Total & 270 & 80 & 16 & \\
\hline
\end{tabular}

bahwa hal ini disebabkan oleh karena internet tetap diperlukan dalam kegiatan belajar sebagai sarana tambahan memperoleh sumber pengetahuan.

Waktu dalam menggunakan internet bervariasi antar individu. Pada penelitian ini durasi menggunakan internet dibagi menjadi durasi penggunaan internet dalam sehari dan durasi penggunaan internet dalam seminggu. Penelitian ini menemukan bahwa durasi penggunaan internet terbanyak pada durasi 2-4 jam sehari. Responden yang mengalami ketergantungan internet ringan mengakses internet paling banyak pada durasi 2-4 jam sehari, sedangkan responden yang mengalami ketergantungan internet sedang menggunakan internet dominan pada durasi $>8$ jam sehari. Durasi penggunaan internet dalam seminggu didapatkan lebih banyak responden menggunakan internet dengan durasi $<40$ jam dalam seminggu. Responden yang mengalami ketergantungan internet ringan lebih banyak menggunakan internet dengan durasi $<40$ jam dalam seminggu, sedangkan responden dengan ketergantungan internet sedang dominan menggunakan internet dengan durasi $>40$ jam dalam seminggu. Hasil termuan penelitian ini menjelaskan hasil temuan penelitian oleh Oghenere S (2018) bahwa adanya hubungan yang bermakna antara waktu yang digunakan untuk berinternet terhadap ketergantungan internet. Dimana semakin lama durasi penggunaan internet akan menimbulkan semakin tingginya kecenderungan mengalami ketergantungan internet dan efek buruk terjadi akibat pemakaian internet itu sendiri. ${ }^{12}$

Subjek yang diteliti didapatkan mengalami ketergantungan internet ringan hingga sedang, namun tidak didapatkan subjek dengan ketergantungan internet berat. Hasil pengolahan data didapatkan bahwa lebih banyak laki-laki yang mengalami ketergantungan internet. Hal ini disebabkan pada saat ini maraknya jenis game online yang tersedia dan mudahnya akses yaitu smartphone dengan kecenderungan laki-laki lebih rentan untuk bermain game. ${ }^{13,14}$ Hasil ini sesuai dengan penelitian oleh Mussarat A, dkk (2014) dimana dalam penelitian tersebut ditemukan laki-laki lebih banyak mengalami ketergantungan internet dibandingkan perempuan. Penelitian tersebut menunjukkan bahwa jenis kelamin mempengaruhi kejadian ketergantungan internet karena laki-laki lebih rentan menggunakan internet yang berlebihan. ${ }^{15}$ Noha A. (2016) dengan sampel penelitian yang lebih besar yaitu 1495 perempuan dan 950 laki-laki menunjukkan hasil yang signifikan antara ketergantungan internet dengan jenis kelamin. Penelitian tersebut 
menjelaskan bahwa laki-laki lebih menghabiskan banyak waktu untuk berinternet seperti untuk bermain game online maupun chatting. ${ }^{16}$ Aviv W, dkk (2015) mendapatkan hasil ketergantungan internet pada subjek laki-laki lebih banyak dibandingkan dengan perempuan walaupun pada penelitian tersebut jenis kelamin tidak bermakna secara statistik dengan ketergantungan internet. Dalam penelitian tersebut dijelaskan bahwa laki-laki lebih cenderung rentan terhadap ketergantungan internet karena laki-laki diharapkan lebih dominan, tangguh, dan tegas. Perempuan lebih diharapkan untuk lembut, baik, dan perasa. Dorongan untuk berhasil pada permainan dan aktivitas di internet dapat menyebabkan laki-laki yang mempunyai sifat ambisius untuk mudah mengalami ketergantungan internet. Perempuan lebih dapat mengontrol diri dibandingkan dengan laki-laki sehingga lebih sulit untuk mengalami ketergantungan internet. ${ }^{17}$ Berbeda dengan penelitian yang dilakukan oleh Elona H. (2016) bahwa perempuan lebih banyak mengalami ketergantungan internet dibandingkan dengan laki-laki. ${ }^{18}$

Proses ketergantungan internet dapat dijelaskan berdasarkan mekanisme biokimiawi, seperti halnya dengan ketergantungan zat, yaitu terjadi disfungsi pada sistem neurotransmitter dopamin. Pada keadaan normal, dopamin akan dilepaskan ke celah sinaptik dan ditangkap oleh reseptornya yang berada pada dinding ujung sel syaraf di celah itu. Pengeluaran dopamine ini akan memberikan respons rasa nyaman pada tubuh, jika proses telah selesai, dopamine akan diambil kembali oleh molekul transporter yaitu dopamine active transporter (DAT) dan dibawa kembali ke neuron asalnya. Pada seseorang yang ketergantungan zat, zat yang masuk ke dalam darah akan memblokir kerja dari DAT hal ini menyebabkan peningkatan jumlah dopamine pada sinaps, diperkirakan seperti itu pula mekanisme pada kecanduan internet. Pada penelitian yang menggunakan pemindaian otak dengan Single Photon Emission Computed Tomography (SPECT) dan didapatkan penurunan jumlah sel membrane DAT pada sampel yang ketergantungan internet. Berkurangnya DAT menandakan bahwa terjadi gangguan pada proses reuptake di terminal sinaps atau adanya gangguan sistem dopaminergik pada otak, sehingga jumlah dopamin di sinaps lebih dari normal. ${ }^{19}$

\section{SIMPULAN}

Berdasarkan hasil penelitian ini dapat disimpulkan bahwa terdapat hubungan yang bermakna antara ketergantungan internet dengan jenis kelamin pada siswa SMPN 2 Denpasar.
Perlu dilakukan penelitian lebih lanjut dengan sampel yang lebih besar dengan data yang lebih beragam demi mencari informasi lain yang dapat memengaruhi angka kejadian ketergantungan internet agar data yang didapatkan lebih akurat.

\section{KONFLIK KEPENTINGAN}

Penulis menyatakan tidak terdapat suatu konflik kepentingan terhadap publikasi dari artikel ini.

\section{PENDANAAN}

Penelitian ini tidak mendapatkan suatu pendanaan yang diberikan oleh pemerintah ataupun lembaga swasta lainnya.

\section{KONTRIBUSI PENULIS}

Konsep penelitian: I Gusti Ngurah Agung Jayadhi Widyakusuma, I Made Darma Yuda, I Gusti Ngurah Made Suwarba. Pengumpulan data, input data dan pengolahan data: I Gusti Ngurah Agung Jayadhi Widyakusuma. Penyusunan naskah Penelitian: I Gusti Ngurah Agung Jayadhi Widyakusuma.

\section{ETIKA DALAM PENELITIAN}

Penelitian ini telah disetujui oleh Komite Etik RSUP Sanglah Denpasar.

\section{DAFTAR PUSTAKA}

1. Rizky E, dkk. Hubungan Kejadian Ketergantungan internet dengan Prestasi Belajar pada Mahasiswa FK Unand. Jurnal Kesehatan Andalas. 2016.

2. APJII. Penetrasi dan Perilaku Pengguna Internet di Indonesia. 2017.

3. Putri Ariani dkk. Relationship between Academic Stress, Family and Peer Attachment with Internet Addiction in Adolescents. 2017.

4. Ifdil I, dkk. Measuring internet addiction: comparative studies based on gender using Bayesian analysis. Journal of Physiscs. 2018.

5. Kristiana SK, dkk. Internet Addiction Among Adolescents in Jakarta: A Chellenging Situation for Mental Health Development. Journal of International Dental and Medical Research. 2018.

6. Sam-Wook, dkk. Comparison of risk and protective factors associated with smartphone addiction and Ketergantungan internet. Journal of Behavioral Addictions. 2015. 4(4), pp. 308-314.

7. Jerald J. Issues for DSM-V: Ketergantungan internet. Am J Psychiatry. March 2008. 165:3.

8. Young K.S. Ketergantungan internet: Symptoms, Evaluation, And Treatment. 1999.

9. Joseph C, dkk. The Development of Compulsive Internet Use and MEntah Health: A Four-Year Study of Adolescence. 2015.

10. Liron BY, dkk. Ketergantungan internet by Using the Smartphone-Relationships between Ketergantungan internet, Frequency of Smartphone Use and the State of Mind of Male and Female Students. Journal of Reward Deficiency Syndrome and Addiction Science. 2016. 
11. Miftahul j, Syarifah R. Kecenderungan Ketergantungan internet pada Mahasiswa. 2017.

12. Oghenere S, dkk. Digital Media Usage and Prevalence of Internet Addiction among Undergraduate Students in South Africa. International Journal of Web Application. 2018.

13. Young K.S. Understanding Online Gaming Addiction and Treatment Issues for Adolescents. 2009.

14. Anderson, E. L., Steen, E., \& Stavropoulos, V. Internet use and problematic Internet use: A systematic review of longitudinal research trends in adolescence and emergent adulthood. International Journal of Adolescence and Youth. 2016. 1, 1-25.

15. Mussarat A, dkk. The Relationship between Ketergantungan internet and Anxiety among students of University of Sargodha. Interntational Journal of Humanities and Social Science. January 2014. Vol. 4 No 1.

16. Noha A, dkk. Ketergantungan internet among School Adolescents in Northeastern Jordan. World Journal of Medical Sciences. 2016. 13 (4): 218-224.
17. Aviv W, dkk. Ketergantungan internet is associated with social anxiety in young adults. Annals of Clinical Psychiatry. 2015.

18. Elona $\mathrm{H}$. Ketergantungan internet and Anxiety among Students of University if Tirana. European Journal of Educational Studies. 2016

19. Muthia A, dkk. Hubungan Tipe Kepribadian Introvert dengan Kecanduan Internet pada Siswa Kelas X di SMAN 1 Banjarmasin. 2014.

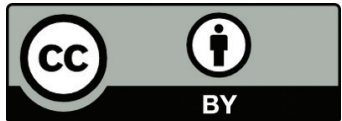

This work is licensed under a Creative Commons Attribution 